\section{Garlic Productivity and Profitability as Affected by Seed Clove Size, Planting Density and Planting Method}

\author{
J.Z. Castellanos, ${ }^{1}$ P. Vargas-Tapia, and J.L. Ojodeagua, G. Hoyos \\ Unidad de Horticultura Intensiva, Instituto Nacional de Investigaciones \\ Forestales, Agrícolas y Pecuarias, Apdo. Postal 112, Celaya, Guanajuato. \\ CP. 38010. Mexico
}

\author{
G. Alcantar-Gonzalez and F.S. Mendez \\ Instituto de Recursos Naturales, Colegio de Posgraduados, Montecillos, Edo. \\ de Mex. CP. 56230. Mexico
}

E. Alvarez-Sanchez

Departamento de Suelos, UniversidadAutónoma Chapingo, km 38.5 carretera Mexico-Texcoco. Chapingo, Edo. de Mex. CP. 56230. Mexico

\section{A.A. Gardea \\ Centro de Investigacion en Alimentacion y Desarrollo, A.C. Cd. Cuauhtemoc, Chih, CP, 83000 Mexico}

Additional index words. leaf area index, drip irrigation, fertigation, yield, market grade of the total production costs in garlic cultivation. The objectives of this study were to analyze the influence of seed clove size, planting density and planting method on yield, bulb size and on the profitability of garlic for the fresh market, planted under fertigation. Two experiments were established to evaluate planting densities ranging from 300,000 to 500,000 plants/ha in the 1998-99 season, and 300,000 to 600,000 plants/ha during the 1999-2000 season. Two additional experiments were established to evaluate the effect of seed size in the range of 1.9 to $10 \mathrm{~g} / \mathrm{clove}$ in 1998-99, and 1.9 to $17 \mathrm{~g} /$ clove in 1999-2000. Seed of Taiwan-type 'Tacatzcuaro' garlic was used in all the experiments. A fifth experiment was established to compare mechanical vs. hand planting. The experimental design in all cases was a randomized complete block with four replicates. For the plant density study, yields varied from 23.5 to $29.9 \mathrm{t}^{-h^{-1}}$ for the first year and from 32.1 to $39.7 \mathrm{t}^{\cdot \mathrm{ha}^{-1}}$ for the second season. For the seed clove size study, yields varied from 18.7 to $27.3 \mathrm{t}^{\cdot} \cdot \mathrm{ha}^{-1}$ for the first year and from 16.3 to $32.2 \mathrm{t}^{\cdot} \mathrm{ha}^{-1}$ for the second season. Yields and leaf area index (LAI) were directly related to planting density and clove size. Highest yields were attained with maximum studied densities in both seasons. However highest profitability was attained with planting densities of 420,000 plants/hafor the first year, as calculated from the regression equation and 300,000 plants/ha for the second year as there was no statistical difference $(P>0.05)$ with the two subsequent population treatments and the former has lower costs than the others. The biggest diameters of bulb were always attained with the lowest population densities. In regard to seed size, the highest yield was achieved with $\mathbf{7 . 5} \mathrm{g} /$ clove for the first season and $\mathbf{1 3} \mathrm{g} /$ clove for the second season, which also resulted in biggest bulb diameters and therefore in more valuable commercial classes. In accordance with the regression analysis, highest profits were obtained with clove sizes 3.6 to $6.5 \mathrm{~g} / \mathrm{clove}$, which yielded from 24 to $27 \mathrm{t}^{\cdot h^{-1}}$ for the first season and from 7 to $10 \mathrm{~g} /$ clove for the second season, for yields from 29 to $31 \mathrm{t}^{\cdot h \mathrm{~h}^{-1}}$. In general, the largest-sized seeds produced lower profits than medium-sized seeds, even though yields were significantly higher. The best planting method for garlic, as evaluated in terms of yield, quality and profitability, was associated with good plant distribution in the field and planting the seed with the apex upwards, characteristics obtained in the hand-planted treatment.

Received for publication 6 May 2003. Accepted for publication $11 \mathrm{Feb}$. 2004. This paper was supported in part by CONACYT, Grant No. 35248-B. We thank Mireille M. Kheirallah for the review of the manuscript.

${ }^{1}$ To whom request for reprints should be addressed; e-mail casteja100@hotmail.com.
Table 1. Commercial classification of 'Tacatzcaro' garlic in terms of bulb diameter and mean bulb weight at harvest and average sale price for 1998-2000 (M.A. Torres, personal communication, 2002).

\begin{tabular}{llccc}
\hline $\begin{array}{l}\text { Class } \\
\text { no. }\end{array}$ & $\begin{array}{l}\text { Commercial } \\
\text { classification }\end{array}$ & $\begin{array}{l}\text { Bulb } \\
\text { diam } \\
(\mathrm{mm})\end{array}$ & $\begin{array}{c}\text { Bulb wt } \\
\text { at harvest } \\
(\mathrm{g})\end{array}$ & $\begin{array}{r}\text { Sale } \\
\text { price } \\
(\$ / \mathrm{kg})\end{array}$ \\
\hline 5 & Tube & $40-45$ & 46 & 0.32 \\
6 & Giant & $45-50$ & 60 & 0.53 \\
7 & Jumbo & $50-55$ & 78 & 0.85 \\
8 & Extra jumbo & $55-60$ & 91 & 0.96 \\
9 & Super jumbo & $60-65$ & 105 & 1.06 \\
10 & Colossal & $65-70$ & 125 & 1.17 \\
11 & Super colossal & $>70$ & 145 & 1.28 \\
\hline
\end{tabular}

${ }^{2}$ Prices are based on the payment received by farmers.
In contrast with many other vegetable crops, garlic seed always represents a high percentage of production costs, even at low planting density and low clove size. Practically all the studies carried out to date on plant density indicate its direct influence on yield (Sotomayor, 1975; Aljaro and Escaff, 1976; Landry and Khanizadeh, 1994; Nourai, 1994; Castillo et al., 1996). The above authors studied planting densities ranging from 100,000 to $1.3 \times 10^{6}$ plants/ha; yet, none was managed to maximize total yield, even at the highest population densities, indicating how sensitive garlic is to this variable. However, the yield improvement occurring at increased plant stand is offset by the reduction in bulb size which severely affects quality and market value, when garlic is produced for fresh market. These results are not applicable to garlic produced for dehydration in which the reduction in bulb size does not affect the value of the harvest. Castillo et al. (1996) studied densities of 104,000 to 400,000 plants/ha under Mediterranean conditions and reported that the favorable effect of high plant stand on yield occurs as a result of an increase in leaf area index (LAI) and its duration. These authors recommended handling plant densities from 140,000 to 180,000 plants/ha to ensure a good bulb diameter, given that bulb quality diminishes at high populations. None of the reported studies to date have carried out a quantitative analysis to optimize profitability.

Various studies, on the other hand, have reported the direct influence of seed size on yield (Duimovic and Bravo, 1979; Lucero et al., 1982) and the quality of the harvested bulb (Burba et al., 1987). Stahlschmidt and Cavagnaro (1997) evaluated seed garlic cloves weighing from 2.5 to $9.8 \mathrm{~g}$ /clove and reported that the biggest seeds produced more vigorous plants, with greater leaf area and with larger bulb diameters than smaller seeds. If we consider the same plant stand, class 10 large seeds (65 to $70 \mathrm{~mm}$ in diameter, Table 1) may cost four times as much as class 5 seeds (40 to $45 \mathrm{~mm}$ ) (M.A. Torres, personal communication, 2002). The former requires almost three times as much seed (in weight) as the latter. It represents a cost of up to 12 times more, thus it increases garlic production costs tremendously. No study regarding seed size has carried out a quantitative evaluation of these variables. Thus, data only indicate the advantage of using medium or large sized seed to obtain better quality bulbs, without specifying the adequate size or diameter from an economic point of view (Duimovic and 

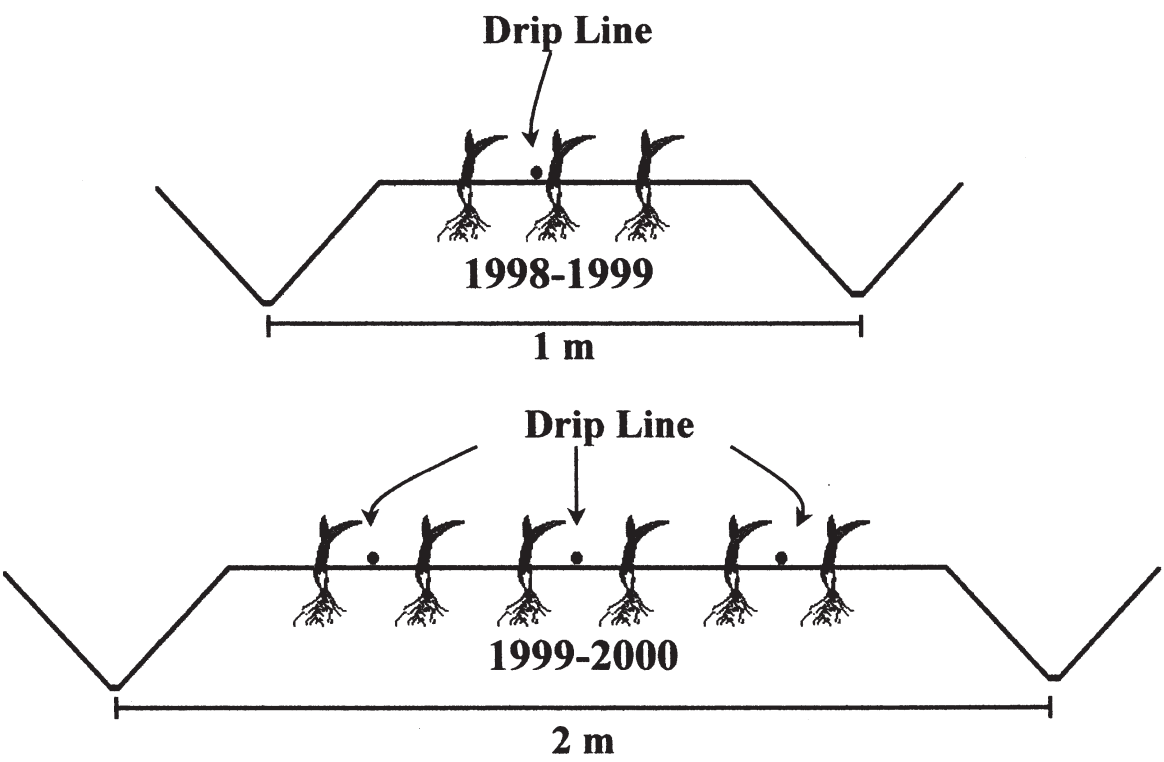

Fig. 1. Geometrical layout of experiments carried out in 1998-99 and 1999-2000.

Bravo, 1979; Lucero et al., 1982; Stahlschmidt and Cavagnaro, 1997).

All the above studies were carried out under furrow irrigation and the yields reported ranged between 5 and $15 \mathrm{t} \cdot \mathrm{ha}^{-1}$. With the advent of drip irrigation, the yield potential has increased up to 3 -fold. Under such water and fertilizer management it is feasible to establish plant populations with a better plant spacing geometry and better plant nutrition. This is why it is important to reconsider studies on clove size and plant population to optimize these variables and achieve high yields without affecting bulb quality, when garlic is produced for fresh market. When garlic is produced for dehydration the target is not bulb size but total yield, produced at a low cost.

Another important variable in garlic production is planting method. Mechanical seed planters deposit cloves randomly with respect to orientation of the clove apex and base. Given garlic seed shape, when the clove is deposited with the apex downwards, emergence is retarded, tends to be uneven, reduces the clove food reserves for the small plants and thus potentially affects yield and quality. In contrast, hand-planting makes it more feasible to place the seed with the apex upwards and equidistant, but it requires a large expense in labor. No information of the effect of this variable on yield and productivity has been published to our knowledge. If seed position does represent advantages in yield and quality, it could encourage agricultural engineers to design a machine capable of planting the seed equidistantly and apex up or at least compensate for the use of hand planting when the cost of labor is affordable.

The objectives of this study were to analyze the effect of seed size and population density on crop yield and profitability under fertigation with garlic produced for the fresh market; and to determine the effect of hand-planting with seed apex up, as opposed to mechanical planting on yield and productivity.

\section{Materials and Methods}

The present study was carried out in the Bajio Experimental Station of the National Institute of Agricultural and Forestry Research (INIFAP), close to the city of Celaya, State of Guanajuato, located in Central Mexico, latitude $20^{\circ} 37^{\prime} \mathrm{N}$ and longitude $101^{\circ} 24^{\prime} \mathrm{W}$.
Two experiments on population density were conducted, one during 1998-99 and the other during 1999-2000 (Expts. 1 and 2). Experiments 3 and 4 were established to study the effect on seed size, one during 1998-99 and the other during 1999-2000. Finally a fifth experiment evaluated the type of planting during the 1999-2000 season (Expt. 5). The same cultivar-Tacatzcuaro-of purple Taiwan garlic (Heredia et al., 1997) was used in all experiments.

During the 1998-99 season, the average minimum temperatures were $14.8,11.6,8.3$, $3.8,2.1,4.9$, and $5.9^{\circ} \mathrm{C}$, the average maxima were $26.8,25.5,27.0,25.5,24.2,25.8$, and $27.8^{\circ} \mathrm{C}$, and precipitation was $200.1,58.6$, $29.0,0.0,8.7,0.0$, and $3.0 \mathrm{~mm}$ for the months of September 1998 through March 1999. The average minimum temperature during the 1999-2000 season was 11.9, 8.9, 5.7, 3.5, 3.4, 5.3, and $6.5^{\circ} \mathrm{C}$, the average maximum 27.3 , $26.5,25.3,23.7,25.0,26.3$, and $33.1^{\circ} \mathrm{C}$, and precipitation was $18.8,2.4,0.0,2.0,0.0,0.0$, and $6.0 \mathrm{~mm}$ for the months of September 1999 through March 2000.

In Expt. 1 (1998-99) three plant densities were evaluated: $300,000,380,000$ and 500,000 plants/ha. Three rows of plants, $17 \mathrm{~cm}$ apart, were planted in $1 \mathrm{~m}$ wide furrows. Distances of 10,8 , and $6 \mathrm{~cm}$ were left between plants to obtain the above densities. Seeds with an average weight at planting of $6 \mathrm{~g} /$ clove, taken from 55 to $60 \mathrm{~mm}$ diameter bulbs (average of 10 cloves/bulb) were planted on 5 Sept. 1998. The soil at the experiment was an isothermic dic pellustert clay, with $2 \%$ organic matter and a $\mathrm{pH}$ of 7.2. A fertilization rate of $285 \mathrm{~N}-35 \mathrm{P}-166 \mathrm{~K}-15 \mathrm{Zn} \mathrm{kg} \cdot \mathrm{ha}^{-1}$ was applied using ammonium nitrate, potassium nitrate, monoammonium phosphate, and zinc sulfate. Nitrogen and $\mathrm{K}$ were applied by drip irrigation on a weekly basis for the first $140 \mathrm{~d}$ of growth, based on the expected requirement; whereas $\mathrm{P}$ and $\mathrm{Zn}$ were banded in the rows prior to planting and seeds were placed $5 \mathrm{~cm}$ apart. Plants were irrigated according to soil moisture tension measured by tensiometers, inserted at a depth of 15 and $30 \mathrm{~cm}$ and 15 $\mathrm{cm}$ apart from the dripping line, maintaining a water tension between -10 and $-20 \mathrm{kPa}$ during the entire growing season. A total irrigation of $77 \mathrm{~cm}$ was applied. Pests and diseases were

Table 2. Garlic bulb yield for each commercial class for Expt. 1 (1998-99) and Expt. 2 (1999-2000) in response to plant densities.

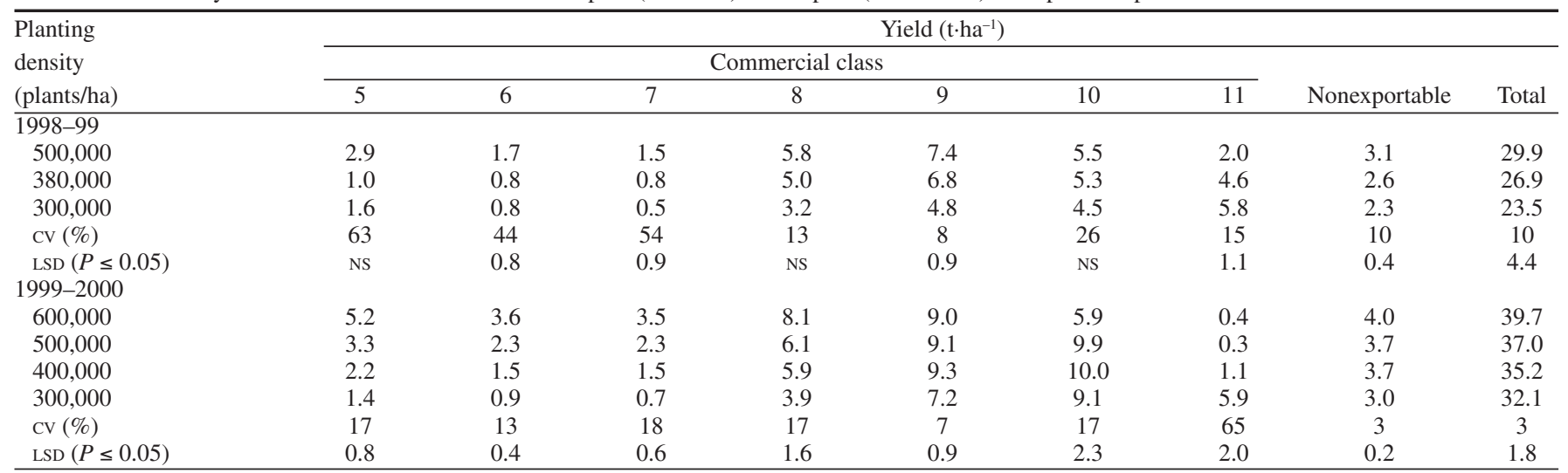

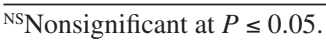




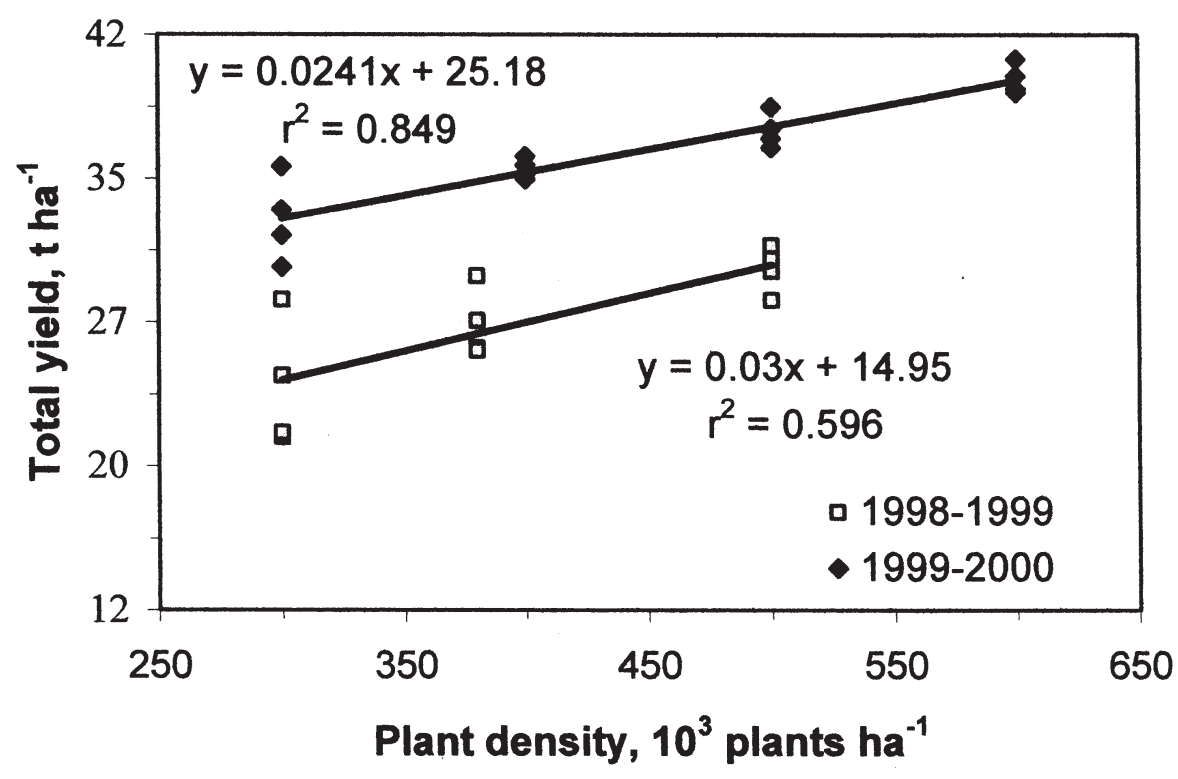

Fig. 2. Total garlic bulb yield as affected by plant density, for Expt. 1 (1998-1999) and Expt. 2 (1999-2000).
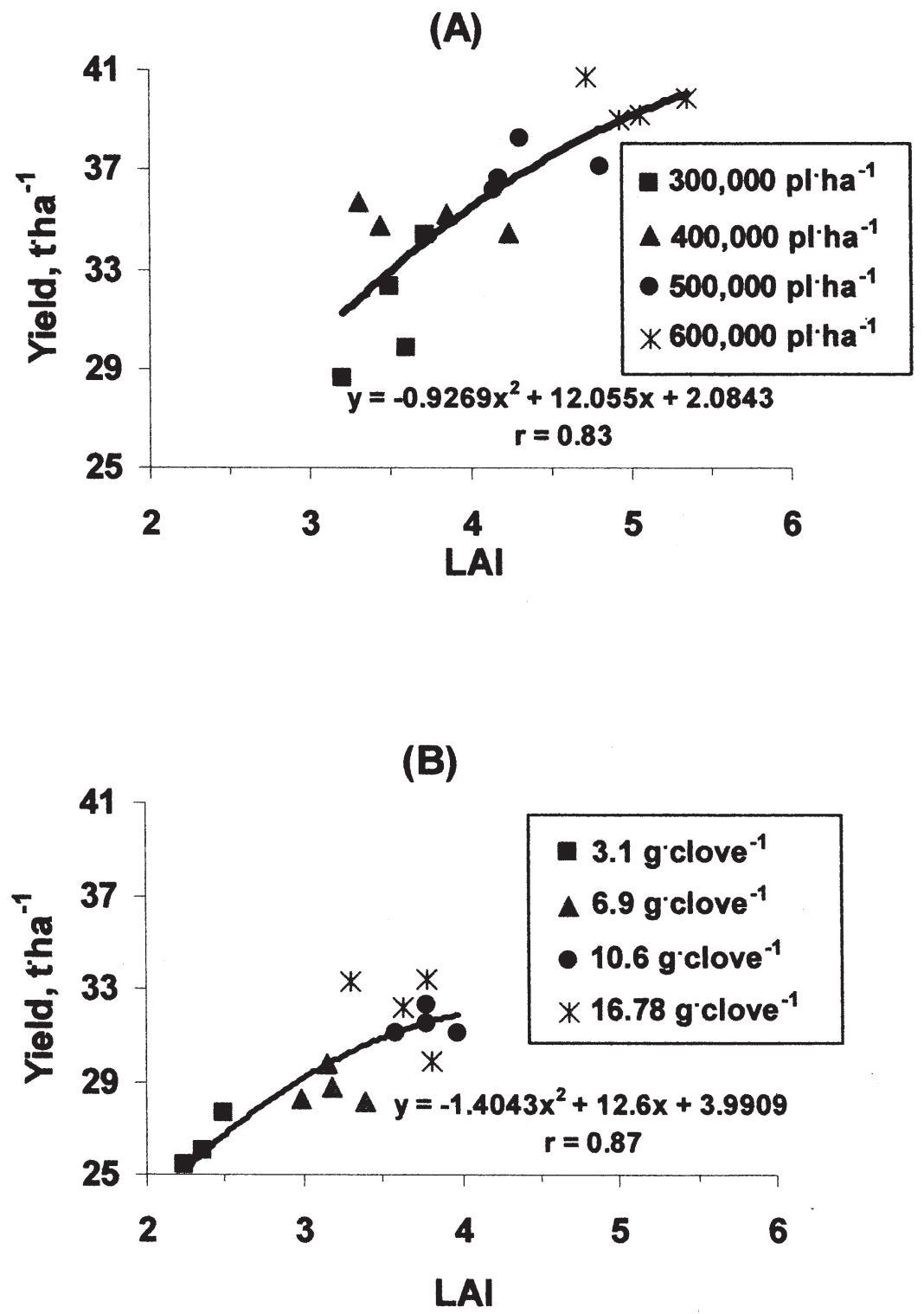

Fig. 3. Relationship between maximum LAI and total yield of bulb for the treatments of population density (a) and seed clove size (b) for Expt. 2 and Expt. 4 (1999-2000). chemically controlled. Harvest was done on 16 Mar. 1999, 193 d after planting (DAP), or 3203 degree days of development (DDD). The criterion for suspending irrigation was the point at which $50 \%$ of the bulbs turned purple between cloves (which was determined by sampling), harvesting $10 \mathrm{~d}$ afterwards.

After harvest, bulbs were cured in the field for $10 \mathrm{~d}$, after which roots and stalks were cut to enable classification into the seven commercial classes illustrated in Table 1 (M.A. Torres, personal communication, 2002). These classes are based on the fresh-market requirements for export into the U.S. and the prices are based on the payment received by farmers. Defective and damaged bulbs were discarded. Bulbs with visible cloves, or those $<40 \mathrm{~mm}$ in diameter, were classified as nonexportable. Production costs and average domestic market value during the period 1998-2001 for central Mexico were considered in the economic analysis. Fixed costs included land cost, insurance, land preparation, fertilization, water, depreciation of irrigation system, cultivation labor, and control of weed, pest and diseases. Variable costs included seed value and seed disinfection, hand harvest, sorting, and packaging costs. Sale prices considered for each of the commercial classes are listed in Table 1.

Experiment 2(1999-2000) was planted on 8 Sept. 1999 with the following population densities 300,000, 400,000, 500,000, and 600,000 plants/ha. Six rows were planted in $2 \mathrm{~m}$ wide beds with three dripping lines (Fig. 1). Seeds were planted $10,7.5,6$, and $5 \mathrm{~cm}$ apart, with $25 \mathrm{~cm}$ between rows, to obtain these population densities. Water and fertilization management were very similar to those in the first experiment, except that in this case $\mathrm{N}$ rate was 400 $\mathrm{kg} \cdot \mathrm{ha}^{-1}$. Maximum LAI was recorded in the four populations at $153 \mathrm{~d}$ after planting or 2411 DDD in the four plant stands using an Accupar Model: PAR-80 Linear PAR/LAICeptometer. The total irrigation applied measured $95 \mathrm{~cm}$. Plants were harvested on 23 Mar. 2000; 197 DAP or 3147 DDD. Harvest and bulb sorting was as in Expt. 1.

Experiment 3 (1998-99) was planted on 5 Sept. 1998 and six clove sizes were evaluated: 1.9, 2.8, 3.6, 4.5, 6.5, and $10.0 \mathrm{~g} / \mathrm{clove}$. Three rows of plants were planted $17 \mathrm{~cm}$ apart in $1 \mathrm{~m}$ beds. Population density was 300,000 plants/ ha, the seeds being deposited $10 \mathrm{~cm}$ apart by hand, with 1 irrigation tape per bed. Experiment 4 was set up on 8 Sept. 1999 and evaluated five clove sizes, weighing 1.2, 3.1, 6.9, 10.6 , and $16.7 \mathrm{~g} /$ clove. In the final treatment, exceptionally large cloves, not corresponding to any commercial class, were used. Six rows of plants were planted $30 \mathrm{~cm}$ apart in $2 \mathrm{~m}$ beds and using two irrigation tapes per bed. Seeds were planted by hand $10 \mathrm{~cm}$ apart to achieve the same density of 300,000 plants/ha(Fig. 1). Plot management was as described for Expts. 1 and 2. Experiment 3 was harvested on 16 Mar. 1999 and Expt. 4 on 23 Mar. 2000, at 193 and 197 DAP respectively. In Expt. 4, maximum LAI was taken at 153 DAP in treatments of $3.1,6.9,10.6$, and $16.7 \mathrm{~g} /$ clove, using the same equipment described above.

Experiment 5 was planted on 8 Sept. 1999 
Table 3. Profitability analysis of different garlic population densities, during Expt. 1 (1998-99) and Expt. 2 (1999-2000).

\begin{tabular}{lccccc}
\hline \multirow{2}{*}{$\begin{array}{c}\text { Treatment } \\
\text { (plants/ha) }\end{array}$} & \multicolumn{3}{c}{$\$ /$ ha } & \\
\cline { 2 - 6 } & $\begin{array}{c}\text { Fixed } \\
\text { costs }\end{array}$ & $\begin{array}{c}\text { Variable } \\
\text { costs }\end{array}$ & $\begin{array}{c}\text { Total } \\
\text { costs }\end{array}$ & $\begin{array}{c}\text { Gross } \\
\text { income }\end{array}$ & $\begin{array}{c}\text { Net } \\
\text { profit }\end{array}$ \\
\hline $1998-99$ & & & & & \\
500,000 & 4,347 & 7,703 & 12,050 & 24,550 & 12,500 \\
380,000 & 4,347 & 6,629 & 10,976 & 24,449 & 13,473 \\
300,000 & 4,347 & 5,661 & 10,008 & 21,372 & 11,364 \\
CV $(\%)$ & & & & 7 & 8 \\
LSD $(P \leq 0.05)$ & & & & 2852 & 1695 \\
$1999-2000$ & 4,939 & 10,153 & 15,092 & 29,836 & 14,744 \\
600,000 & 4,939 & 9,157 & 14,096 & 31,788 & 17,692 \\
500,000 & 4,939 & 8,245 & 13,184 & 29,812 & 16,628 \\
400,000 & 4,939 & 7,248 & 12,187 & 29,572 & 17,385 \\
300,000 & & & & 3 & 5 \\
CV $(\%)$ & & & & 1220 & 1213 \\
LSD $(P \leq 0.05)$ & & & & & \\
\hline
\end{tabular}

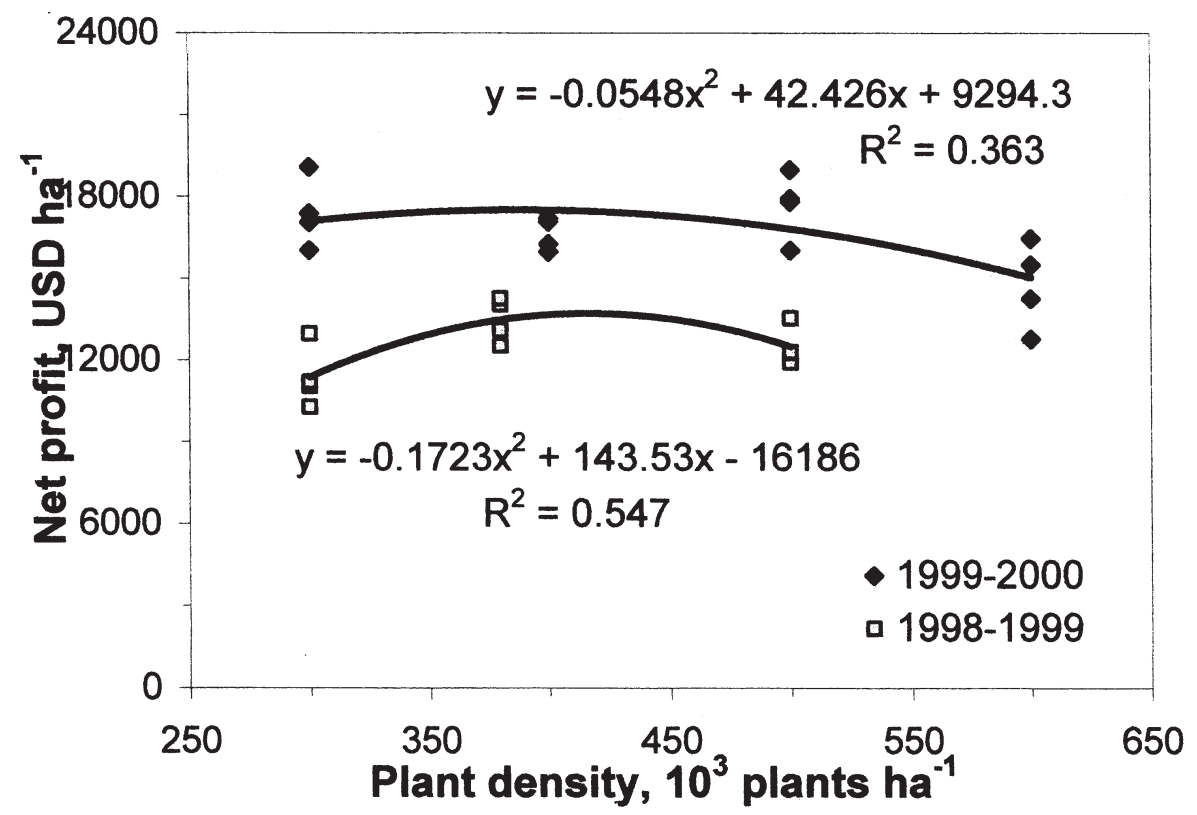

Fig. 4. Net profit as affected by plant density in garlic, for Expt. 1 (1998-1999) and Expt. 2 (1999-2000).

to compare machine and hand planting. A Feyma planting machine (model 150; TPP, Inc. Cuenca, Spain) deposited seed unevenly, approximately $10 \mathrm{~cm}$ apart. Hand planting was carried out with the same geometric arrangement, although seeds were deposited equidistantly, $10 \mathrm{~cm}$ apart with apex up, unlike machine planting where the seed could fall in any position. Seed was planted with a population density of 300,000 plants/ha. Water management, fertilization, and harvest time were as those used in Expt. 4. In all experiments the experimental design was a randomized block with four replications. The SAS (1995) statistical package was used for statistical analyses. Differences among treatments within each commercial class were assessed with a LSD test $(P>0.05)$. Regression analysis examined the relationship between plant density, seed size, and maximum yield and profit.

\section{Results and Discussion}

Population density. Data for garlic bulb yield from Expts. 1 and 2 are presented in Table 2 and Fig. 2. In both years it was observed that as planting density increased, total yield increased significantly with a linear response in the studied range $(P>0.01)$. Yield decline was not achieved, even with the highest population density. These results agree with other authors reporting yield, (Duimovic and Bravo, 1979; Lucero et al., 1982) and bulb size at harvest (Burba et al., 1987), as affected by planting density. However, those authors reported yields of only 5 to $15 \mathrm{t} \cdot \mathrm{ha}^{-1}$, much lower than those found in our study, even using far higher populations than those used in our experiments. In fact, the yield obtained of nearly $40 \mathrm{t} \cdot \mathrm{ha}^{-1}$ at 600,000 plants/ha in Expt. 2 , is the highest reported so far. The greater yield from this experiment can be attributed to a better geometric planting arrangement in the $2 \mathrm{~m}$ beds (Fig. 1), where it is likely that LAI is maximized more quickly than in the 1 $\mathrm{m}$ beds. As plant population increased, yield of classes with greatest commercial value (9, 10 , and 11$)$ decreased significantly $(P>0.05)$. Garlic yield in the super colossal class (class 11), increased notably from 0.4 to $5.9 \mathrm{t} \cdot \mathrm{ha}^{-1}$, when population density was reduced from 600,000 to 300,000 plants/ha. This commercial class has a very high economic value, which indicates the potential of the lowest population for obtaining larger size bulbs with a greater market price. In general, these results are congruent with those reported by Castillo et al. (1996). However, it is important to note that our study reports sizes of a much larger diameter than those reported by that author. In our study, 3.8 and $0.7 \mathrm{t} \cdot \mathrm{ha}^{-1}$ of bulbs with a diameter $>75 \mathrm{~mm}$ were harvested in Expts. 1

Table 4. Total garlic bulb yield for each commercial class for Expt. 3 (1998-99) and Expt. 4 (1999-2000), given the different seed size evaluated.

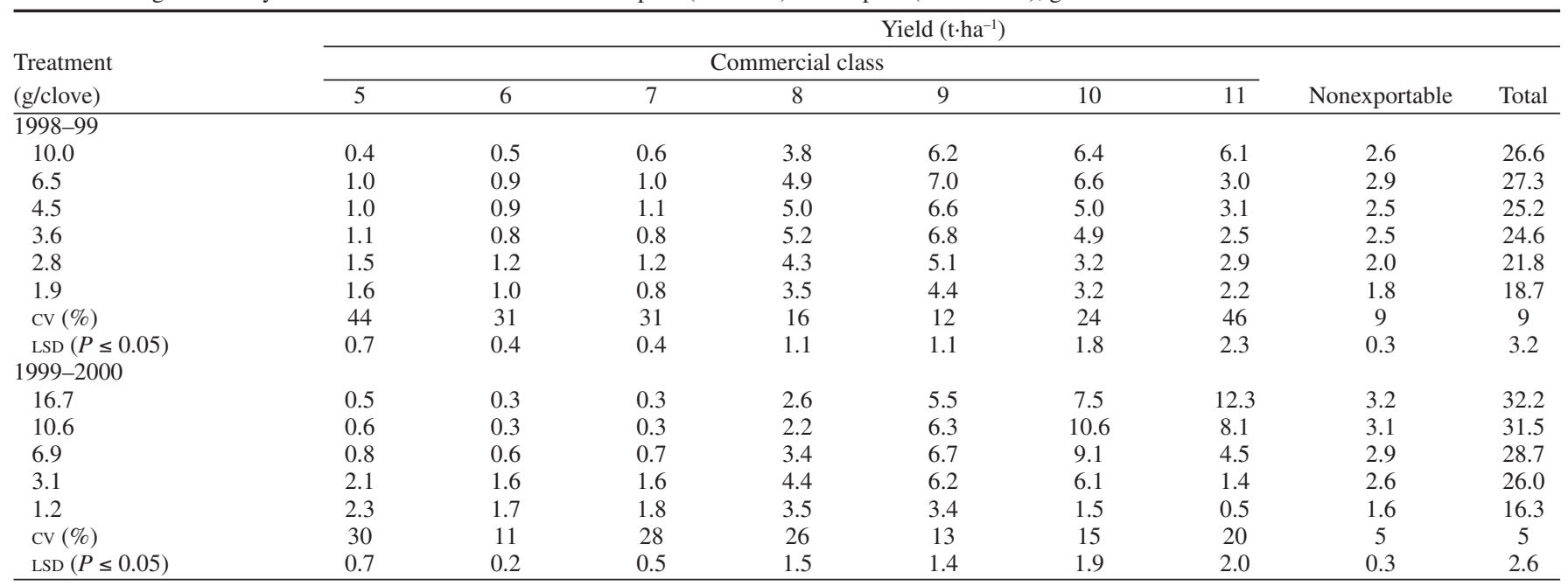




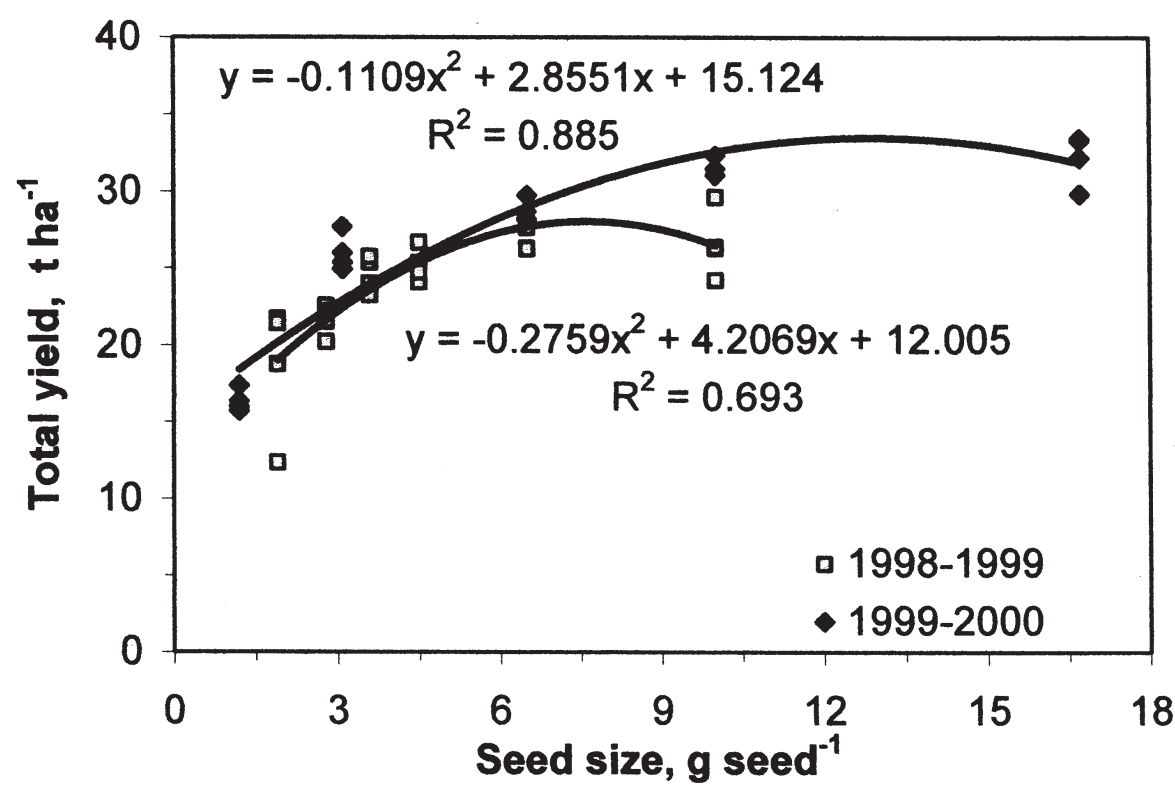

Fig. 5. Total garlic bulb yield as affected by seed size for Expt. 1 (1998-1999) and Expt. 2 (1999-2000).

Table 5. Profitability analysis for the different garlic seed sizes, for Expt. 3 (1998-99) and Expt. 4 (1999-2000).

\begin{tabular}{lccccc}
\hline $\begin{array}{l}\text { Treatment } \\
\text { (g/clove) }\end{array}$ & \multicolumn{5}{c}{$\$$ /ha } \\
\cline { 2 - 6 } & $\begin{array}{c}\text { Fixed } \\
\text { costs }\end{array}$ & $\begin{array}{c}\text { Variable } \\
\text { costs }\end{array}$ & $\begin{array}{c}\text { Total } \\
\text { costs }\end{array}$ & $\begin{array}{c}\text { Gross } \\
\text { income }\end{array}$ & $\begin{array}{c}\text { Net } \\
\text { profit }\end{array}$ \\
\hline $1998-99$ & 4,347 & 8,949 & 13,296 & 25,335 & 12,038 \\
10.0 & 4,347 & 6,608 & 10,955 & 24,416 & 13,461 \\
6.5 & 4,347 & 4,933 & 9,280 & 22,449 & 13,169 \\
4.5 & 4,347 & 4,249 & 8,596 & 21,701 & 13,105 \\
3.6 & 4,347 & 3,637 & 7,984 & 18,451 & 10,467 \\
2.8 & 4,347 & 3,090 & 7,437 & 15,682 & 8,245 \\
1.9 & & & & 10 & 18 \\
CV $(\%)$ & & & & 3197 & 3193 \\
LSD $(P \leq 0.05)$ & 4,939 & 16,667 & 21,606 & 31,647 & 10,041 \\
$1999-2000$ & 4,939 & 10,322 & 15,261 & 30,513 & 15,252 \\
16.7 & 4,939 & 7,484 & 12,424 & 26,552 & 14,128 \\
10.6 & 4,939 & 4,906 & 9,845 & 21,490 & 11,645 \\
6.9 & 4,939 & 3,354 & 8,293 & 11,962 & 3,669 \\
3.1 & & & & 4 & 10 \\
1.2 & & & & 1598 & 1680 \\
CV $(\%)$ & & & & & \\
LSD $(P \leq 0.05)$ & & & & & \\
\hline
\end{tabular}

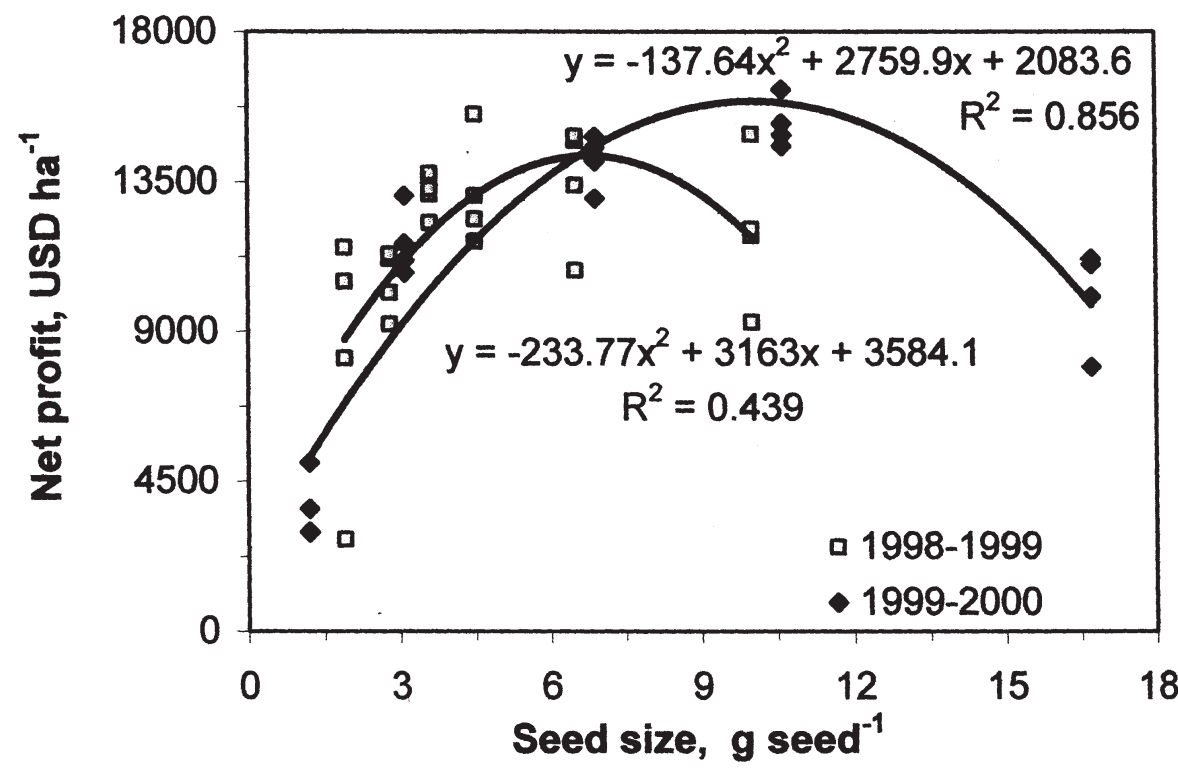

Fig. 6. Net profit of garlic as affected by seed size for Expt. 1 (1998-99) and Expt. 2 (1999-2000). and 2, respectively (data not shown). Although these bulbs fell into the super colossal class, their diameter was notably greater than their specification, conferring additional benefits.

Figure $3 \mathrm{~A}$ shows the relationship between maximum LAI and bulb yield in the population density treatments obtained in Expt. 2. Maximum LAI values reached 5.4 at a population density of 600,000 plants/ha. The maximum level previously reported for this crop was a LAI of 2.9, which yielded $15 \mathrm{t} \cdot \mathrm{ha}^{-1}$ (Castillo et al., 1996). In our work, a similar LAI was associated with a bulb yield far greater than that reported by those authors. This could possibly indicate the greater yield potential of the genotype used in our study (Heredia et al., 1997). When population density increased from 300,000 to 600,000 plants/ha, maximum LAI increased from 3.4 to 5.4. This could explain the yield increase from 32.3 to $39.7 \mathrm{t} \cdot \mathrm{ha}^{-1}$.

Table 3 and Fig. 4 present the economic analysis of each of the population density treatments over the 2-year period. Data from Expt. 1, indicated that 500,000 plants/ha yielded $>3 \mathrm{t} \cdot \mathrm{ha}^{-1}$ more than the treatment of 380,000 plants/ha. Profits, however, were not statistically different, because of the increased production costs of the highest population. From the regression analysis it was calculated that a population density of 387,000 plants/ha, resulted in the highest profit for Expt. 1.

In Expt. 2, 300,000 plants/ha resulted the most convenient population density as there was no statistical difference $(P>0.05)$ with the two subsequent population treatments and the former has lower costs. That population density produced a yield of $7.6 \mathrm{t} \cdot \mathrm{ha}^{-1}$ less than the 600,000 plants/ha treatment. Again, the low yield of the low population density is compensated by larger bulb size, and consequently, higher market value. Although gross income is similar in all treatments, costs are higher at the high-density treatments, because the larger quantity of seed required; which is the most expensive input in the production process.

Seed size. Garlic yields resulting from the clove size experiments are shown in Table 4 and Fig. 5. Experiment 3 (1998-99) demonstrated how the use of smaller sized seed severely affected crop yield, as well as bulb diameter. A difference of $8 \mathrm{t} \cdot \mathrm{ha}^{-1}$ was obtained between seeds of 1.9 and $6.5 \mathrm{~g} /$ clove, whereas seeds $>6.5 \mathrm{~g}$ /clove did not produce an increase in yield, but it produced a significant increase in bulbs of the highest commercial class $(P>$ 0.05). Data from Expt. 4 (1999-2000) showed a similar tendency, although clove size used was greater in this growing cycle. Total yield continued to increase when seed cloves heavier than $6.9 \mathrm{~g}$ were used, even using seed weighing $16.7 \mathrm{~g} /$ clove. Although total yield did not significantly $(P>0.05)$ exceed that of the 10.6 $\mathrm{g} /$ seed treatment, the quality was significantly improved $(P>0.05)$. There was a significant increase $(P>0.05)$ in bulbs falling into the highly valued class 11 . Regression analysis showed optimum seed size of 7.6 and $12.9 \mathrm{~g}$ for the two experiments.

These results are congruent with those reported by Duimovic and Bravo (1979); Lucero et al. (1982); Burba et al. (1987) and 
Table 6. Total garlic bulb yield for each commercial class in Expt. 5 (1999-2000) depending on planting methods evaluated.

\begin{tabular}{|c|c|c|c|c|c|c|c|c|c|}
\hline \multirow{3}{*}{$\begin{array}{l}\text { Planting } \\
\text { treatment }\end{array}$} & \multicolumn{9}{|c|}{ Yield $\left(\mathrm{t} \cdot \mathrm{ha}^{-1}\right)$} \\
\hline & \multicolumn{7}{|c|}{ Commercial class } & \multirow[b]{2}{*}{ Nonexportable } & \multirow[b]{2}{*}{ Total } \\
\hline & 5 & 6 & 7 & 8 & 9 & 10 & 11 & & \\
\hline Hand & 1.2 & 0.8 & 0.7 & 3.5 & 6.5 & 8.3 & 7.3 & 3.1 & 31.4 \\
\hline Mechanical & 1.2 & 0.7 & 0.7 & 2.7 & 5.5 & 7.6 & 5.5 & 2.6 & 26.5 \\
\hline $\mathrm{CV}(\%)$ & 20 & 17 & 17 & 23 & 10 & 8 & 23 & 7 & 7 \\
\hline $\operatorname{LSD}(P \leq 0.05)$ & NS & NS & NS & NS & NS & NS & NS & NS & 4.7 \\
\hline
\end{tabular}

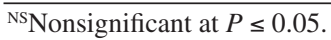

Table 7. Profitability analysis of the two planting methods in Expt. 5 (1999-2000).

\begin{tabular}{lccccc}
\hline & \multicolumn{5}{c}{$\$ /$ ha } \\
\cline { 2 - 6 } $\begin{array}{l}\text { Planting } \\
\text { treatment }\end{array}$ & $\begin{array}{c}\text { Fixed } \\
\text { costs }\end{array}$ & $\begin{array}{c}\text { Variable } \\
\text { costs }\end{array}$ & $\begin{array}{c}\text { Total } \\
\text { costs }\end{array}$ & $\begin{array}{c}\text { Gross } \\
\text { income }\end{array}$ & $\begin{array}{c}\text { Net } \\
\text { profit }\end{array}$ \\
\hline $1999-2000$ & & & & & \\
Hand & 4,939 & 7,094 & 12,033 & 29,114 & 17,081 \\
Mechanical & 4,676 & 6,480 & 11,157 & 24,388 & 13,231 \\
CV $(\%)$ & & & & 8 & 7 \\
LSD $(P \leq 0.05)$ & & & & 4681 & 2460 \\
\hline
\end{tabular}

Stahlschmidt and Cavagnaro (1997). However, none of these previous studies worked with seed as large. A large-sized seed is capable of developing a larger LAI than a small seed, this in turn is reflected in greater yield (Fig. 3B). It is noteworthy that a greater carbohydrate and mineral seed reserve produces a strong plant that establishes more quickly and develops better than those from a small seed. This effect has been reported for other species (Brewster, 1985; Chalermpone et al., 1986; Mondal et al., 1986; White and Hoogenboom, 1996. Krishnamurthy and Bhatnagar, 1998), but given the size of garlic seeds, this variable has a great effect on crop yield.

It is possible that such spectacular results in the genetic improvement of garlic reported by Heredia et al. (1997), basing selection on the number of cloves, are partially due to the fact that a bulb with few cloves produces large individual seeds. This in turn contributes to a greater bulb yield, but does imply the use of a greater amount of seed.

A profitability analysis for different seed sizes is shown in Table 5, and the relationship between seed clove size and net profit is shown in Fig. 6. In Expt. 3 (1998-99), the greatest profit was obtained from seeds weighing 3.6 to $6.5 \mathrm{~g}$. The differences in net profit between these two seed sizes were only marginal. In accordance to regression analysis, maximum profits are obtained with $7.6 \mathrm{~g} / \mathrm{seed}$ given that production costs rise greatly if larger sized seed is used, whereas gross income increases only slightly. In contrast, in Expt. 4, although seed weighing $16.7 \mathrm{~g} /$ clove produced greater yield, more profitable sizes were attained with lower seed sizes. Largest sized seeds require greater quantities, which in turn increases the production costs and even though higher revenue is obtained, profit is lower. From the regression analysis the maximum profit for Expt. 4 was attained with $12.9 \mathrm{~g} /$ clove. In Expt. 4, yields were higher than in Expt. 3;probably because the crop responded to a bigger seed clove size in the second year.

Planting systems. Table 6 shows the results from the two planting methods evaluated in Expt. 5. Planting by hand, which places seeds equidistantly with apex up, produces a greater yield than mechanical planting, with seeds deposited randomly in distance and position. This difference reached $4.9 \mathrm{t} \cdot \mathrm{ha}^{-1}$ in favor of hand planting. Although no significant difference was found between individual classes, the increase in overall yield was significant $(P>0.05)$. Hand planting represents higher costs, yet larger income compensates for this operative point of view, it is difficult to hand plant areas exceeding 10 ha in Mexico. Nevertheless, there are a large number of medium and small scale producers, who are able to plant by hand in Mexico. Lower labor costs in Mexico and other developing countries confers a certain advantage on hand-planting systems. Notwithstanding, the data in this study indicate the benefit of developing a machine able to deposit the seed apex up, equidistantly.

\section{Conclusions}

From an economic point of view, and for the fertigated planting systems used, the best planting densities for fresh garlic production were between 300,000 to 420,000 plants/ha, given that large sized bulbs with a greater market value are achieved. The best seed size ranged from 3.6 to $6.5 \mathrm{~g} /$ clove, corresponding to classes $5 \& 7$. Only under production conditions that lead to a very high yield potential (above $30 \mathrm{t} \cdot \mathrm{ha}^{-1}$ ) can very large seed size (up to $10 \mathrm{~g} /$ clove) be expected to have economic advantages. Larger sized seed or higher planting densities may produce significantly greater yields, but with lower market classes, and the lower priced bulbs that decrease overall profit. The best planting method, according to yield, quality and profit, was spaced equidistant by hand with apex up.

\section{Literature Cited}

Aljaro, A. and M. Escaff. 1976. Fertilización nitrogenada y densidad de plantación en cultivos de ajo (Allium sativum L.). Agricultura Técnica 36(2):63-68.

Brewster, J.L. 1985. The influence of seedling size and carbohydrate status and of photon flux cost, as shown in Table 7. However, from an density during vernalization on inflorescence initiation in onion (Allium cepa L.). Ann. Bot. 55:403-414.

Burba, J.L., J.A. Saluzzo, and M.P. Blanci. 1987. Propuesta de modificación del sistema de manejo cultural del ajo. I: Efecto de la densidad de plantación y el tamaño del bulbillo "semilla" sobre el rendimiento de Ajo (Allium sativum L.) T.C. Rosado paraguayo. Horticultura Argentina 6(12-14):137-145

Castillo, J.E., L. López-Bellido, E.J. Fernández, and F.J. López. 1996. Influence of planting geometry on growth, yield and quality of rainfed garlic ( $\mathrm{Al}$ lium sativum $\mathrm{L}$.) cultivated under Mediterranean conditions. J. Hort. Sci. 71(6):867-879.

Chalermpone, S., J. Somjit, and K. Mengampun. 1986. The effect of seed size and plant density on growth and yield of peanut. J. Agric. (Thailand) 2(2):173-184.

Duimovic, M. and A. Bravo. 1979. Efectos del peso de bulbillos semilla y población de plantas sobre el rendimiento y calidad del ajo blanco. (Effects of seed-bulbils weight and plant population on yield and quality of white garlic.) Cienc. Invest. Agrar. 6:99-103.

Heredia-Zepeda, A., E. Heredia-Garcia, and J.A. Laborde. 1997. Number of cloves per bulb; selection criteria for garlic improvement. II Results with "Taiwan" type. Acta Hort. 433:271-277.

Krishnamurthy, L. and V.B. Bhatnagar. 1998. Growth analysis of rainfed mustard (Brassica juncea (L.) Coss. \& Czern.) cv. Varuna. Crop Research Hisar. 15(1):43-53.

Landry, B.S. and S. Khanizadeh. 1994. Comparative yield and evaluation of cultural practices for selected fall-planted garlic lines (Allium sativum L.) in Quebec. Can. J. Plant Sci. 74:353-356.

Lucero J.C., C. Andreoli, M. Reyzabal, and V. Larreguy. 1982. Influencia del peso del bulbillo y densidad de plantación sobre el rendimiento y calidad de ajo Colorado (Allium sativum L.). Anales de Edafol. Agrobiol. 40:1807-1811.

Mondal, M.F., J.L. Brewster, E.L. Morris, and H.A. Butler. 1986. Bulb development in onion (Allium cepa L.). III. Effects of the size of adjacent plants, shading by neutral and leaf filters, irrigation and nitrogen regime and the relationship between the rad:far-red spectral ratio in the canopy and leaf area index. Ann. Bot. 58:207-219.

Nourai, A.H. 1994. Effects pf plating methods and seed rates on yield, yield components, and quality of garlic (Allium sativum L.) in the Sudan. Acta Hort. 358:359-364.

SAS Institute. 1995. ANOVA. In: SAS user guide: Statistics. SAS Inst., Cary, N.C.

Sotomayor, R.I. 1975. Efecto de la fertilización nitrogenada y densidad de plantas en la producción de ajos. Agricultura Técnica 35(4):175-178.

Stahlschmidt, O. and J.B.Cavagnaro. 1997. Influence of plating date seed cloves size on leaf area and yield of two garlic cultivars (Allium sativum L.). Acta Hort. 433:519-525.

White, J.W. and G. Hoogenboom. 1996. Simulating effects of genes for physiological traits in a process-oriented crop model. Agron. J. 88(3):416-422 